\title{
Analisis Hubungan Pengetahuan Petugas Panti Tentang Pemenuhan Kebutuhan Activity Daily Living Pada Lanjut Usia
}

\author{
Tomi Jepisa ${ }^{1}$, Radian Ilmaskal ${ }^{2}$ \\ ${ }^{1,2}$ Keperawatan, Sekolah Tinggi Ilmu Kesehatan Alifah Padang, Jln. Khatib Sulaiman No 52B, Kota Padang, \\ Kode Pos: 25000, Indonesia \\ Email: ${ }^{1}$ tomikhalis@gmail.com, ${ }^{2}$ radian.ilmaskal@gmail.com
}

\begin{abstract}
Abstrak
Kemampuan lansia dalam memenuhui kebutuhan Activity Daily Living yang tinggal di Panti Sosial Tresna Werdha diantaranya kebutuhan makan, mandi, berpakaian, toileting, kontinesia dan berpindah tidaklah semudah sewaktu muda kala, oleh karena itu petugas panti sosial harus mempunyai kemampuan dan pengetahuan yang tinggi. Hal tersebut dapat dilihat dimana adanya lansia yang ketergantungan dalam kebutuhan mandi dan toileting. Disini peran dan pengetahuan petugas panti sangat dibutuhkan sekali agar terjaga kebersihan lansia, terhindar dari penyakit dan lansia dapat secara mandiri dalam memenuhui kebutuhan ADL nya. Tujuan penelitian ini untuk mengetahui dan menganalisis pengetahuan petugas panti tentang Activity Daily Living (ADL) dengan pemenuhan kebutuhan ADL pada lansia yang tinggal di Panti Sosial Tresna Werdha Propinsi Sumatera Barat. Jenis penelitian ini analitik dengan pendekatan Cross Sectional. Populasi penelitian seluruh petugas PSTW dengan sampel 51 orang. Hasil penelitian didapatkan sebagian besar petugas panti berpengatahuan baik (60.8\%) pemenuhan ADL pada lansia yang tinggal di PSTW sebagian besar kurang (68.6\%). Kesimpulan dalam penelitian ini ditemukan ada hubungan pengetahuan tentang ADL dengan pemenuhan ADL pada lansia yang tinggal di PSTW Propinsi Sumatera Barat.
\end{abstract}

Kata kunci: ADL, Petugas panti, Pengetahuan

\section{Relationship Analysis of Worker's Knowledge of The Needs of Activity of Daily Living In The Elderly}

\section{Abstract}

The ability of the elderly to meet the needs of Activity Daily Living in Nursing home such as bathing, dressing, toileting, continence and moving is not as easy as when young, therefore the social care staff of West Sumatera Province must have high ability and knowledge. This can be seen where there are elderly who depend on the need for bathing and toileting. Here the role and knowledge of the orphanage officer is very much needed to keep the elderly clean and avoid disease and the elderly can independently fulfill their Activity Daily Living (ADL) needs. The purpose of this study was to determine and analyze the knowledge of the orphanage staff about Activity Dayli Living by fulfilling the needs of Activity Daily Living in the elderly who live in PSTW, West Sumatera Province. This type of analytic research with Cross Sectional approach. The study population was all PSTW officers with a sample of 51 people. Questionnaire research instrument. The results showed that most of the welleducated orphanage workers (60.8\%) fulfillment of Activity Daily Living in the elderly living in nursing home were mostly lacking (68.6\%). The conclusion in this study found there is a relationship of knowledge about Activity Daily Living with the fulfillment of Activity Daily Living in the elderly who live in Nursing Home West Sumatera Province.

Keywords: Activity Daily Living orphanage staff, PSTW and Knowledge 


\section{PENDAHULUAN}

Keberhasilan program kesehatan dalam suatu negara maupun program pembangunan sosial ekonomi ini tergambar dari presentasi peningkatan usia harapan hidup suatu penduduk negara. Indonesia merupakan salah satu negara berkembang yang jumlah penduduknya sudah diatas enam puluh tahun dimana terjadi peningkatan jumlah penduduk dari tahun ketahun. Populasi lansia memiliki kecendrungan meningkat dimana sekarang penduduk lansia di Indonesia menurut data dunia tercatat pertumbuhan paling pesat sejak tahun 2000. Laporan perserikatan bangsabangsa pada tahun 2011, dimana persentase populasi lansia dunia semenjak tahun 2000 sebanyak $7.74 \%$ dari jumlah penduduk bahkan di prediksi jumlah pertumbuhan lansia akan meningkat menjadi $28.68 \%$ pada tahun 2045. Hal ini menunjukan bahwa penduduk lansia di dunia terus bertambah dan meningkat (Kemenkes RI, 2013).

Masa transisi jumlah usia harapan hidup terus meningkat jika dibandingkan masa sebelumnya. Dalam kurun waktu sejak tahun 1990 sampai tahun 2002 pertumbuhan Pertambahan jumlah lansia di Indonesia termasuk yang tercepat di dunia. Dimana terdapat 16 juta jumlah lansia pada tahun 2002, bahkan diperediksi akan bertambah pada tahun 2020 nanti sebanyak 25.5 juta lansia jumlah di Indonesia, jika di bandingkan negara lain Indonesia termasuk negara ke empat jumlah penduduk lansia terbanyak setelah negara china, India dan Amerika Serikat (Badan Pusat Statistik, 2015).

Pertambahan jumlah usia secara alamiah tentu menyebabkan kemampuan secara fisik, mental, dan bahkan hubungan sosial akan berkurang. Maka aspek kesehatan pada lansia perlu di fokskan dalam menjaga kondisi anatomi dan fungsi organ tubuhnya dikarenakan sudah tidak sempurna seperti kala berusa remaja maupun dewasa. Hubungan sosial kemasyarakatan sangat penting diperhatikan karena perhatian dan perawatan terhadap diri sendiri terjadi penurunan baik secara kuatitas maupun secara kualitas (Nurkusuma D, 2001).
Secara hakekatnya menjadi tua merupakan proses yang pasti secara alamiah akan di lalui artinya seseorang telah melalui proses tiga tahap kehidupan di antaraya proses masa anak-anak, proses masa dewasa, dan proses masa tua. Jadi tiap proses dalam tiga tahap ini berbeda baik secara psikologis maupun secara biologis. Seseorang memasuki masa tua secara alamiah akan mengalami perubahan fisik maupun psikis. Adapun perubahan fisik yang dialami seseorang ditandai dengan kulit yang mengendor, rambut yang sudah mulai memutih, terjadinya penurunan pendengaran, gerakan lambat, penglihatan yang sudah mulai kabur, kelainan berbagai fungsi organ vital, dan kurang gairah. Perubahan ini pada umumnya berpengaruh juga pada aktivitas hubunga sosial, karena adanya kemunduran kesehatan fisik dan psikis, serta terjadinya ketidak mandirian Lansia dalam melakukan aktivitas kehidupan sehari-hari (Nugroho, 2008).

Seiring dengan bertambahnya usia seseorang, maka secara perlahan terjadi keterbatasan seseorang (lansia) dalam melakukan activity of daily living (ADL). Berdasarkan laporan sensus American community survey $28 \%$ lansia yang telah berusia diatas 65 tahun terdapat keterbatasan lansia dalam melakukan aktivitas sehari-hari. Adapun keeterbatasan aktivitas yang sering dikeluhkan lansia seperti mandi, berpindah dan berjalan. Keterbatasan aktivitas mandi yang dialami lansia yang telah berusia $\geq 85$ tahun ditemukan 35\% lansia, pada rentang usia $75-84$ tahun sebesar $15 \%$ lansia. Adapun keterbatasan lansia untuk berpindah dari duduk ke tempat tidur pada usia 75-84 ditemukan sebanyak $15 \%$ lansia dan usia $\geq$ 85 tahun dengan persentase sebesar 30\% kondisi ini akan semakin bertambah bila pemahaman dalam memenuhui ADL lansia tidak terpenuhui (Administration on Aging, 2013).

Pertambahan usia seseorang akan mempengaruhui memenuhui kebutuhan ADL ketergantungan lanjut usia ini disebabkan oleh kondisi fisik dan psikis lansia yang mengalami kemunduran, sehingga menyebabkan lansia mengalami ketergantungan dalam menjalankan 
aktivitasnya sehari-hari. Laporan BPS tahun 2015 di Indonesia sendiri nilai rasio ketergantungan lansia dalam memenuhi ADL ditemukan sebanyak $12,71 \%$, sementara itu di Sumatera Barat sendiri menempati peringkat ke- 6 secara nasional tingkat ketergantungan lansia. Tingginya angka ketergantungan ini maka keluarga maupun pengasuh lansia lainnya memiliki beban yang berat dalam memenuhui kebutuhan ADL lansia itu sendiri (Badan Pusat Statistik, 2015).

Sebagai petugas panti yang professional perlu mengetahui perawatan yang dapat diberikan pada Lansia dengan faktor kemandirian lansia untuk mencegah penyakit lebih lanjut, mengetahui kepribadian lansia dan pola tempat tinggal lansia, maka dari itu salah satunya adalah mengetahui faktor kemandirian Lansia. Oleh karena itu perlu pengkajian lebih lanjut tentang faktor apa saja yang berhubungan dengan kemandirian pada lansia. Panti tresna werdha propinsi Sumatra Baratada dua yang berada di Sicicncin Kabupaten Padang Pariaman dan Kabupaten Tanah Datar yang memiliki jumlah lansia, yakni sebanyak 180 jiwa. Hasil penelitian (Alfyanita, Martini, \& Kadri, 2016) di PSTW Sabai Nan Aluih Sicincin ditemukan 54,5\% lansia tidak mandiri dalam melakukan aktivias kehidupan sehari-hari.

Berdasarkan hasil wawancara dengan pengurus panti kasih sayang ibu Batusangkar didapatkan data lansia yang tinggal dipanti tersebut 70 orang, yang dapat melakukan ADL secara mandiri sebanyak 55 orang, sedangkan 15 orang lansia masih tergantung kepada petugas panti. Peranan petugas dalam hal ini membantu memenuhi kebutuhan lansia sesuai perubahannya secara komperehensif sehingga tetap eksis dan aktif dalam tercapainya optimal aging dengan mengupayakan potensi yang masih dimilikinya untuk mencapai keadaan adaptif. Dengan menilai status kesehatan lansia dapat dikaji kemampuannya melaksanakan ADL serta pengkajian terhadap dampak dari kemunduran tersebut sehingga mempengaruhi lansia yang menyebab terjadinya disfungsi sosial seperti harga diri, hubungan interpersonal dan kinerja. Banyaknya jumlah Lansia di PSTW propinsi Sumatra barat dan banyaknya masalah ADL menjadi alasan bagi peneliti untuk memilih wilayah tersebut menjadi lokasi penelitian.

Tujuan penelitian ini adalah untuk mengetahui Analisis hubungan antara pengetahuan petugas panti tentang Activity Dayling Living dengan pemenuhan kebutuhan Activiy Dayling Living pada lansia di panti sosial Tresna Werdha propinsi Sumatra Barat.

\section{METODE PENELITIAN}

Desain penelitian menggunakan deskritif korelasi dengan menggunakan pendekatan cross sectional. Dengan populasi dalam penelitian ini adalah seluruh petugas panti sosial tres werdha dengan pengambilan sample total populasi yang berjumlah sebanyak 51 orang dengan pelaksanaan survey dilakukan pada minggu ke III April sampai minggu ke II Juni 2019 dengan menggunakan uji korelasi atau dengan tingkat kepercayaan $95 \%$.

\section{HASIL DAN PEMBAHASAN}

\section{A. Karakteristik Responden}

Jumlah responden dalam penelitian ini ialah 51 orang. Responden yaitu seluruh petugas PSTW yang ada di PSTW propinsi Sumatera Barat. Distribusi frekuensi responden berdasarkan umur, jenis kelamin dan tingkat pendidikan dalam penelitian adalah sebagai berikut:

Tabel 1

Distribusi Frekuensi Responden Berdasarkan Umur, Jenis Kelamin dan Tingkat Pendidikan Pada Petugas PSTW di Sumatera Barat

\begin{tabular}{lcc}
\hline \multicolumn{1}{c}{ Karateristik } & $\begin{array}{c}\text { frekuensi } \\
\text { (f) }\end{array}$ & $\begin{array}{c}\text { Presentase } \\
\text { \% }\end{array}$ \\
\hline Umur & & \\
\hline$\leq 30$ tahun & 13 & 25,5 \\
$>30$ tahun & 38 & 74,5 \\
\hline Jenis kelamin & & \\
\hline Laki-laki & 27 & 52,9 \\
Perempuan & 24 & 47,1 \\
\hline
\end{tabular}




\begin{tabular}{lcc}
\hline $\begin{array}{l}\text { Tingkat } \\
\text { Pendidikan }\end{array}$ & \\
\hline Tidak Tamat SD & 0 & 0 \\
SD & 5 & 9,8 \\
SMP & 5 & 9,8 \\
SMA & 13 & 25,5 \\
PT & 28 & 54,9 \\
\hline
\end{tabular}

Berdasarkan tabel 1 diketahui sebagian besar responden ditemukan di rentang usia diatas 30 tahun $(74,5 \%)$. Lebih dari separoh responden berjenis kelamin laki-

Tabel 4

Hubungan Pengetahuan Petugas

Panti tentang ADL dengan

Pemenuhan Kebutuhan ADL

pada Usia Lanjut di PSTW

Sumatera Barat

\begin{tabular}{|c|c|c|c|c|c|c|c|}
\hline \multirow{3}{*}{$\begin{array}{l}\text { Pengeta- } \\
\text { huan }\end{array}$} & \multicolumn{4}{|c|}{$\begin{array}{c}\text { Pemenuhan } \\
\text { Kebutuhan ADL }\end{array}$} & \multirow{2}{*}{\multicolumn{2}{|c|}{ Total }} & \multirow{3}{*}{$\begin{array}{c}P \\
\text { Value }\end{array}$} \\
\hline & \multicolumn{2}{|c|}{ Kurang } & \multicolumn{2}{|c|}{ Baik } & & & \\
\hline & f & $\%$ & f & $\%$ & $\mathbf{f}$ & $\%$ & \\
\hline Kurang & 10 & 100 & 0 & 0 & 10 & 100 & \\
\hline Cukup & 5 & 50 & 5 & 50 & 10 & 100 & \\
\hline Baik & 20 & 64,5 & 11 & $\begin{array}{c}35, \\
5\end{array}$ & 31 & 100 & 0,040 \\
\hline Total & 31 & 56,4 & 24 & $\begin{array}{c}43, \\
6\end{array}$ & 51 & 100 & \\
\hline
\end{tabular}

laki $(52,9 \%)$. Persentase tingkat pendidikan responden terbanyak adalah PT yaitu sebanyak $54,9 \%$.

\section{B. Tingkat Pengetahuan}

Distribusi frekuensi pengetahuan petugas PSTW adalah sebagai berikut:

Tabel 2

Distribusi Frekuensi Pengetahuan pada Petugas PSTW yang ada di Sumatera Barat

\begin{tabular}{ccc}
\hline Pengetahuan & $\begin{array}{c}\text { Frekuensi } \\
(\mathbf{f})\end{array}$ & $\begin{array}{c}\text { Persentase } \\
(\mathbf{\%})\end{array}$ \\
\hline Kurang & 10 & 19,6 \\
Cukup & 10 & 19,6 \\
Baik & 31 & 60,8 \\
\hline Total & $\mathbf{5 1}$ & $\mathbf{1 0 0}$ \\
\hline
\end{tabular}

Hasil penelitian pada tabel 2 diketahui sebagian besar responden memiliki pengetahuan yang baik mengenai activity dayling living (ADL) yaitu sebanyak 60,8\% pada PSTW yang ada di propinsi Sumatera Barat.

\section{Pemenuhan Kebutuhan ADL}

Distribusi frekuensi pemenuhan kebutuhan ADL oleh petugas PSTW adalah sebagai berikut:

Tabel 3 Distribusi Frekuensi Pemenuhan Kebutuhan ADL oleh Petugas PSTW yang ada di propinsi Sumatera Barat

\begin{tabular}{ccc}
$\begin{array}{c}\text { Pemenuhan } \\
\text { Kebutuhan } \\
\text { ADL }\end{array}$ & $\begin{array}{c}\text { Frekuensi } \\
\text { (f) }\end{array}$ & $\begin{array}{c}\text { Persentase } \\
(\mathbf{\%})\end{array}$ \\
\hline Kurang & 35 & 68,6 \\
Baik & 16 & 31,4 \\
\hline Total & $\mathbf{5 1}$ & $\mathbf{1 0 0}$ \\
\hline
\end{tabular}

Hasil penelitian pada tabel 3 diketahui bahwa sebagian besar $(68,6 \%)$ responden memenuhi kebutuhan ADL pada lansia pada PSTW yang ada di Sumatera Barat.

\section{Hubungan Pengetahuan Petugas Panti tentang ADL dengan Pemenuhan Kebutuhan ADL pada Usia Lanjut di PSTW Sumatera Barat}

Hasil penelitian pada tabel 4 menunjukkan bahwa kurangnya pemenuhan kebutuhan ADL banyak dilakukan oleh petugas PSTW yang memiliki pengetahuan baik mengenai ADL, yaitu sebanyak $64,5 \%$. Dibanding dengan pengetahuan cukup maupun baik. Hasil uji statistik diperoleh $p$ value sebesar $0,040(\mathrm{p}<0,05)$, artinya adanya hubungan yang bermakna antara pengetahuan petugas panti dengan pemenuhan kebubtuhan ADL pada lansia yang tinggal di PSTW propinsi Sumatera Barat.

Berdasarkan hasil uji statistik didapatkan hasil $p$ value $=$ (kurang 0,05) dimana hasil hubungannya positif dengan nilai 0,040 sehingga dapat dimaknai dimana adanya hubungan antara pengetahuan petugas panti dalam pemenuhan ADL pada lansia yang ada di PSTW. Artinya semakin baik pengetahuan petugas panti dalam pemenuhan ADL maka semakin baik pula tindakan petugas panti dalam pemenuhan ADL pada lansia yang ada di PSTW. Secara alamiah 
lasia dipastikan akan mengalami penurunan dalam kemampuan memenuhui ADL maupun kemampuan fisik dan psikis serta penurunan pada peran sosial ditengah masyarakat. Kemampuan fisik akan menurun disertai fungsi organ tubuh umumnya juga menurun, sehingga kemampuan lansia dalam melakukan aktifitas kehidupan sehari-hari juga menurun dan akan berefek positif dalam melakukan aktifitas kehidupan sehari-hari mengalami berkurang dan tidak mandiri lagi. Keadaan tersebut mengalami lansia butuh pertolongan orang lain dalam memenuhui kebuuhan ADL yang meliputi kebutuhan mandi, kebutuhan toileting, kontenensia serta kebutuhan berpakaian. Oleh sebab itu lansia dalam pemenuhan ADL lansia yang tinggal di panti membutuhkan bantuan orang lain disekitarnya dalam hal ini lansia yang tinggal di panti pemenuhan ADL lansia merupakan tanggung jawab petugas panti. Pemenuhan kebutuhan dasar lansia tidaklah semudah memenuhui kebutuhan usia muda, dimana terjadinya perubahan fisik danlainnya pada lansia. Oleh sebab itu petugas panti harus memeliki dan mempunyai pengetahuan serta keterampilan tertentu dalam hal pemenuhan ADL lansia tersebut. Dalam pemenuhan kebutuhan dasar lansia tergantung dari orang lanjut usia, keluarga dalam hal ini petugas panti dan lingkungan sekitarnya, dimana jika pemenuhan ADL tersebut tidak terpenuhui maka akan timbul masalah dan menurunkan kemandirian lansia (Noorkarsiani, 2009).

Hasil penelitian ditemukan sebanyak $(60.8 \%)$ responden mempunyai pengetahuan tentang tingkat kemandirian ADL lansia baik. Hasil penelitian yang sama dilakukan oleh (Sri Sat Titi Hamranani, 2013) di PSTW Yokyakarta dimana pengetahuan petugas panti cukup (53.3\%) dengan pemenuhan ADL cukup (66.7\%).

Beberapa teori menyatakan pengetahuan seseorang dapat dipengaruhui oleh beberapa faktor, diantaranya teori (Notoatmodjo, 2012), penegatahuan dipengaruhui oleh beberapa faktor diantaranya umur, jenis kelamin, Pendidikan dan lain-lain. Hasil penelitian didapatkan sebnyak (74.5\%) umur petugas PSTW berada pada rentang 30 tahun keatas. Dimana jika dianalisis usia tersbeut berda dalam rentang usia produktif atau pada usia pertengahan dimana apat diketahui di usia tersebut pola pemikiran sudah matang, sehingga pada usia tersebut sudah bias menilai seara objektif antara kenyataan dan harapan yang dapat diterima saat itu juga. Daya tangkap dan pola pikir seseorang juga dapat dipengaruhui oleh usia. Dimana semakin bertambah usia maka semakin berkembang pola piker dan daya tangkap seseorang, sehungga pengetahuan yang didapat semakin mudah untuk dicerna atau semakin mudah diperoleh. Pada usia pertengahan ini, dimana seseorang akan lebih mudah berperan aktif dalam masyarakatun kehidupan sosial lainnya maupun persiapan demi suksesnya penyesuain diri menuju usia tua, selain itu pada usia pertengahan ini banyak waktu luang yang dapat digunakan untuk membaca sehingga menambah kemampuan wawasan atau intelektual, baik pemecahan maslah maupun kemampuan verbal (Notoatmodjo, 2012) Dapat dibuktikan dari hasil penlitian dimana dari 7 responden (56\%) dengan usia diatas 30 tahun memiliki pengatahuan dan melakukan pemenuhan ADL yang baik pada lansia nyang tinggal di panti.

Dalam pengetahuan pemenuhan ADL lansia jenis kelamin juga dapat membedakan pemunuhan ADL lansia, terlihat dari hasil penelitian ini dimana menunjukan bahwa petugas panti $(52.9 \%)$ berjenis kelamin lakilaki. Hasil penelitiaan di UPT PSUL Jember, ditemukan juga dimana jenis kelamin perempuan mempunyai tingkat kemandirian ADL lebih rendah di banding laki-laki (17.14\%). Menurut Watson (Nina Dwi Setyani, 2016) seorang yang berjenis kelamin laki-laki memiliki kemampuan dan kekuatan yang lebih tinggi dalam kemandirian dalam pemenuhan kebutuhan sehari-hari. Dalam penelitian ini juga dapat juga ditemukan dimana tingkat pendidikan juga mempengaruhui penetahuan petugas panti dalam pemenuhan kebutuhan ADL lansia terbukti ditemukan tingkat Pendidikan petugas panti lebih dari separoh (54.9\%) berpendidikan tamatan pergutruan tinggi dan masih ada petugas panti yang berpendidikan SMP dan SMA dimana ditemukan dalam pengetahuan pemberian ADL pada lansia rendah $(35.3 \%)$. Hasil penelitian ini juga dikuatkan oleh penelitian (Fadhia et al., 2012) 
di UPT PSUL Pasuruan dimana hasilnya ditemukan kemandirian dalam melakukan ADL pada lansia dapat dipengaruhui oleh tingkat Pendidikan seseorang. Pendidikan pada dasarnya tidak hanya dapat dibangku sekolah atau tempat formal, tetapi Pendidikan juga bias dilingkungan keluarga, masyarkat dan dari media lainnya seperti majalah, media, dan lain-lain. Belajar merupakan proses perubahan dari belum mampu menjadi mampu dan terjadi dalam jangka waktu tertentu dan dengan belajar umat manusia dapat mewujudkan apa yang dicita-citakan, dan mampu meningkatkan perekonomian dan membantu manusia lainnya.

\section{SIMPULAN}

Adapun kesimpulan hasil penelitian ini bahwa lebih dari separo petugas panti di Panti Sosial Tresna Werdha mempunyai pengetahuan baik tentang activity daily living pada lanjut usia dan terdapat hubungan pengetahuan petugas panti dengan pemenuhan ADL pada lansia.

\section{UCAPAN TERIMA KASIH}

Akhir kata penulis mengucapkan terima kasih yang sebesar-besarnya kepada Kemenristekdikti yang telah memberikan dukungan dana hibah penelitian kami dan civitas akademika STIKes Alifah Padang yang telah memberikan dukungan secara moril sehingga penelitian ini selesai dengan batas aktu yang telah ditentukan.

\section{DAFTAR PUSTAKA}

Administration on Aging. (2013). Aging Statistic. Retrieved from http://www.aoa.acl.gov/Aging_Statistics /Profile/2013/16.aspx

Alfyanita, A., Martini, R. D., \& Kadri, H. (2016). Hubungan Tingkat Kemandirian dalam Melakukan Aktivitas Kehidupan Sehari-Hari dan Status Gizi pada Usia
Lanjut di Panti Sosial Tresna Werdha Sabai Nan Aluih Sicincin. Jurnal Kesehatan Andalas, 5(1), 201-208.

Badan Pusat Statistik. (2015). Indikator sosial ekonomi indonesia. Badan Pusat Statistik Indonesia. Jakarta: Badan Pusat Statistik.

Dinas Sosial propinsi Sumatra Barat. (2018). Profil Dinas Sosial propinsi Sumatra Barat. Padang: Dinas Sosial propinsi Sumatra Barat.

Fadhia, N., Ulfiana, E., \& Ismono, S. R. (2012). Hubungan Fungsi Kognitif Dengan Kemandirian Dalam Melakukan Activity of Daily Living (ADL) Pada Lansia di UPT PSLU Pasuruan. Comunity Health Nursing, 1(1), 87-92.

Kemenkes RI. (2013). Situasi dan Analisis Lanjut Usia dan Gambaran Kesehatan Lanjut Usia di Indonesia. Jakarta: Kemenkes RI.

Nina Dwi Setyani, et al. (2016). Hubungan Tingkat Kemandirian Activity Daily Living (ADL) Dengan Kualitas Hidup Lansia di UPT PSLU Jember.

Universitas Muhamadiyah Jember, 1(2), 1-12. Jember: Universitas Muhamadiyah Jember.

Noorkarsiani, T. S. (2009). Kesehatan Usia Lanjut dengan Pendekatan Asuhan Keperawatan. Jakarta: Salemba Medika.

Notoatmodjo, S. (2012). Metodologi Penelitian Kesehatan. Jakarta: Rineka Cipta.

Nugroho, W. (2008). Gerontik \& Geriatrik. Jakarta: EGC.

Nurkusuma D, D. (2001). Profil Pukesmas Pare Kabupaten Temanggung.

Temanggung: Puskemas Pare.

Sri Sat Titi Hamranani. (2013). Hubungan Pengetahuan Petugas Panti Tentang Tingkat Kemandirian ADL Dengan Pemenuhan ADL Pada Lansia Di PSTW Yogyakarta. Motorik, 8(16), 17-23. 